\title{
Diversity of property regimes of Mediterranean coastal lagoons in S. France; implications for coastal zone management
}

\author{
De Wit Rutger ${ }^{1,{ }^{*}}$, Chaubron-Couturier Pénélope ${ }^{1,2}$, Galletti Florence ${ }^{2}$
}

\begin{abstract}
${ }^{1}$ MARBEC, Université de Montpellier, CNRS, IRD, Ifremer, Bât. 24, Place Eugène Bataillon, CC 093, 34095, cedex 5, Montpellier, France

2 MARBEC, Université de Montpellier, CNRS, IRD, Ifremer, Station Ifremer, Avenue Jean Monnet, CS 30171, 34203, Sète, France
\end{abstract}

* Corresponding author : Rutger De Wit, email address : rutger.de-wit@umontpellier.fr

\begin{abstract}
:
We provide a cartography of the current property regimes of permanent coastal lagoons along the coastlines of the Mediterranean Sea for continental France and Corsica, which include both private and public properties. In France, for the latter, the State Domain Code and the General Code of the property of public persons make a clear difference between Public Domain and private property of the different public entities. Public domain represents property that is imprescriptible and inalienable, i.e. the property rights cannot be changed in the future and neither transferred nor sold to somebody else. In contrast, private properties of public entities can be sold or transferred to thirds. Maritime Public Domain (DPM) was created since 1681. DPM has accommodated Public Domain for the French coastal lagoons following their legal definition as "salty ponds (French étangs salés) with a direct, natural and permanent connection with the sea". However, private landlords battled juridically with the State for centuries both by attacking the pertinence of this definition and claiming ancestral property rights. As a result, before 1980, more than half of the coastal lagoons comprised private properties, representing about a quarter of the lagoon surface. Twelve of 40 coastal lagoons comprise DPM, mainly the larger lagoons (e.g., Salses-Leucate, many lagoons close to Narbonne, Thau lagoon, Berre lagoon), representing $65 \%$ of the total lagoon surface. Since its foundation in 1975, the Conservatoire du Littoral, a public body in charge of coastal nature protection, has bought private coastal lagoons properties in twenty of 40 lagoons, representing $22 \%$ of the total lagoon surface. These have been designated as inalienable and imprescriptible "Public Domain of the Conservatoire", safeguarded for nature conservation purposes. Nowadays, private ownership still persists in 13 lagoons representing 3.3\% of total surface. The Coastal lagoons in Roussillon (Etangs du Canet and Salses-Leucate), the Hérault department, in the Camargue and in Corsica currently show variable and sometimes fragmented ownership (in addition to the Conservatoire, DPM, private ownership, municipalities, departments). Fragmented ownership is a clear difficulty for the integrated management of coastal lagoons. With currently, $87 \%$ of the coastal lagoons as Public Domain, public law and the environmental code have to evolve to tackle the challenges for the conservation and management of coastal lagoons and their connectivity with the other ecosystems on land and in the sea.
\end{abstract}




\section{Graphical abstract}

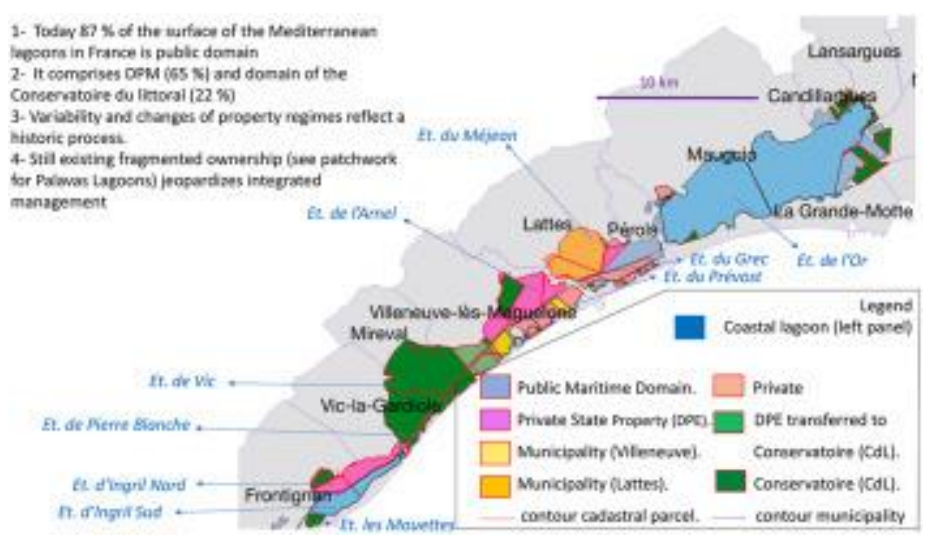

\section{Highlights}

Today $87 \%$ of the surface of the Mediterranean lagoons in France is public domain. DPM (65\%) and domain of the Conservatoire du littoral (22\%). Variability and changes of property regimes reflect a historic process. - Still existing fragmented ownership jeopardizes integrated management.

Keywords : Property regimes, Coastal lagoons, Maritime public domain, Commons, Nature conservation, Governance, Coastal law, Marine protected areas 


\section{Introduction}

In many countries, e.g. France, Spain, Portugal, Greece, Turkey and several states in the USA, the national coastal seas and the coastlines are public properties often legally owned by these national States. This can be considered as a legacy of the public domain defined by Roman Law (Fenn Jr, 1925). Such property regimes are important both for defining who will have access to these ecosystems, rights for natural resource extraction (Schlager and Orstrom, 1992) and other human uses. The public domain is open for use by the citizens of these states. It is, however, clear that in many cases the second principle of Hugo Grotius, i.e., anything can be used without loss to anyone else is often not applicable in the coastal lagoons, which are therefore not fully a space res omnium communis (Thompson, 2005). Rather the uses need to be regulated by Government or by the local communities as in Community-based management (Berkes, 2006). Coastal lagoons have been used by coastal populations since prehistoric times. Traditional uses include fishing, hunting, navigation and salt-extraction (Anthony et al. 2009; De Wit et al., 2019). More recently, particularly since the $19^{\text {th }}$ century, aquaculture, tourism and recreational uses have become increasingly common in coastal lagoons. Finally, there is increasing awareness of the need for protecting the coastal biodiversity, particularly by creating protected areas for the conservation of habitats and species. Coastal lagoons represent a so-called priority habitat $\left(\mathrm{N}^{\circ} 1150 *\right.$ ) according the EU Habitats Directive (1992), meaning that member states should protect the coastal lagoons and assure their conservation status (De Wit et al., 2020). The Convention on Biological Diversity (CBD) recognizes sovereign rights over biodiversity within national territories (Thompson, 2005), which include the coastal zones. Hence, property regimes in coastal lagoons have to be considered for implementing biodiversity conservation in these ecosystems.

Coastlines are transient both on short-term and long-term timescales, as sea level elevation varies along astronomic and meteorological cycles and land may accrete or erode. This creates difficulties in delineating the public property along the coastline (Yavuz Özalp and Akıncl, 2016) with sometimes subtly different approaches within the same State (McGlashan et al., 2005). In addition, the delineation can be further confused by the presence of transient environments. In this paper, we study the property regimes of the Mediterranean coastal lagoons in S. France. In this country, many of the coastal 
lagoons, but not all, belong to the maritime public domain (In French: Domaine Publique Maritime, abbreviated as DPM). This is based on the French law on the Public Maritime Domain (28 November 1963) and article 2111-4 of the French General Code of the property of public persons (Code général de la propriété des personnes publiques, see website), which states that the DPM includes (ii) the floor and below-floor earth layers of those "saline ponds" that communicate, in a natural way, permanently with the sea. In the official French text, the article uses the term "étangs salés"; étang translates as pond or pool (Harrap's dictionary), while it is used in vernacular language for the coastal lagoons in South France and used for the official geographic names, as e.g. Etang de Vic. The wording of the French legal text may thus create a conflict with the scientific definition of a coastal lagoon. according the most commonly accepted definition in coastal sciences, coastal lagoons are described as "inland water bodies, found on all continents, usually oriented parallel to the coast, separated from the ocean by a barrier, connected to the ocean by one or more restricted inlets which remain open at least intermittently, and have water depths which seldom exceed a few meters" (Kjerve, 1994).

The aim of this paper is to document the current property regimes in French Mediterranean coastal lagoons and discuss their implications for the management of these coastal ecosystems, with a particular focus on nature conservation, natural resource extraction and other human uses. In addition, the aim is to understand the genesis of the current situation, particularly the existence of the private ownership and, therefore, two hypotheses can be forwarded for explaining private properties of coastal lagoons, i.e.,

H1: The private property existed in the past before the DPM was implemented and has been passed through inheritance,

$\mathrm{H} 2$ : The legal text is not sufficiently precise to include all types of coastal lagoons and this has favoured the takeover of properties by private persons or institutions.

Finally, we will discuss the actions to be taken to improve the current situation, particularly with respect to conservation of coastal lagoons. 


\section{Study site and methods}

\subsection{Study sites}

Study sites include the permanent coastal lagoons along the Mediterranean coastlines of continental France and the island of Corsica. These coastal lagoons occur in three administrative Regions, i.e., i) Occitanie (littoral zone of the Gulf of Lion, where they occur along 50 \% of the coastline), ii) Province-Alpes-Côte d'Azur and iii) Corsica (littoral of the Tyrrhenian Sea). In French étangs littoraux is the generic name for coastal lagoons, and the word Étang, used in their official geographic names, is abbreviated hereafter as Et. (e.g., Etang de Vic written as Et. de Vic). Coastal lagoons are separated from the sea by a coastal barrier and have permanent or temporary connections with the adjacent sea through one or several inlets (Kjerve, 1994). Nowadays in most of the French Mediterranean lagoons the inlets have been modified by humans to assure a permanent connection with the sea. Naturally-moving inlets still occur for the Etangs de La Palme and Ayrolle in Occitanie, and several lagoons in Corsica. Several of the coastal lagoons in deltaic settings have been separated by several km's from the sea by progression of the delta, while still connecting with the sea through wetlands or artificial canals.

The lagoons close to Montpellier have been heavily modified. Originally, the Etang de Mergueil was a large lagoon that ranged from Frontignan (close to Etang de Thau) in the SW up to the Camargue in the NE. This lagoon has been compartmentalized by canals, dikes and roads into 10 different 'étangs', i.e. the larger Etang de l'Or and a complex of nine water bodies designated as the Palavas Lagoon Complex (in French Complexe lagunaire palavasien). Only two of these water bodies (Et. d'Ingril Sud, Et. du Prévost) have an inlet connecting directly to the Mediterranean Sea. The building of the Rhôneto-Sète canal, which started in the $18^{\text {th }}$ century, has separated four permanent lagoons (Etangs de l'Ingil Nord, de Vic, de l'Arnel, and du Méjean) from the coastline and exchanges of these lagoons with the sea occur through this canal. Etangs de Pierre Blanche and le Grec are located on the coastline and separated from the sea by a barrier without an inlet; these two lagoons also exchange with the sea through the Rhône-toSète canal.

\subsection{Methods}


French legal text and historical documents were studied to describe the specificities of current French law and the chronology of its implementation. Most of the French text is now available on-line on internet at the website Légifrance

(https://www.legifrance.gouv.fr) and the pertinent sections are mentioned in the reference list.

The cartography was based on using Q-GIS (version La Palma 2.18.15). Shapefiles for coastal lagoons were obtained from the Data bases Ocsol in Occitanie and PACA and CORINE land cover for Corsica (CLC 521). Shapefiles for cadastral parcels and municipalities for coastal lagoons were obtained from the French national geographic institution (IGN). Openstreet maps were used as a plug-in. Information of properties regimes were obtained from documents, the website for the Conservatoire du littoral, the website of the Direction départementale des territoires et de la mer (DDTM), and interviews with coastal zone managers.

Timeline

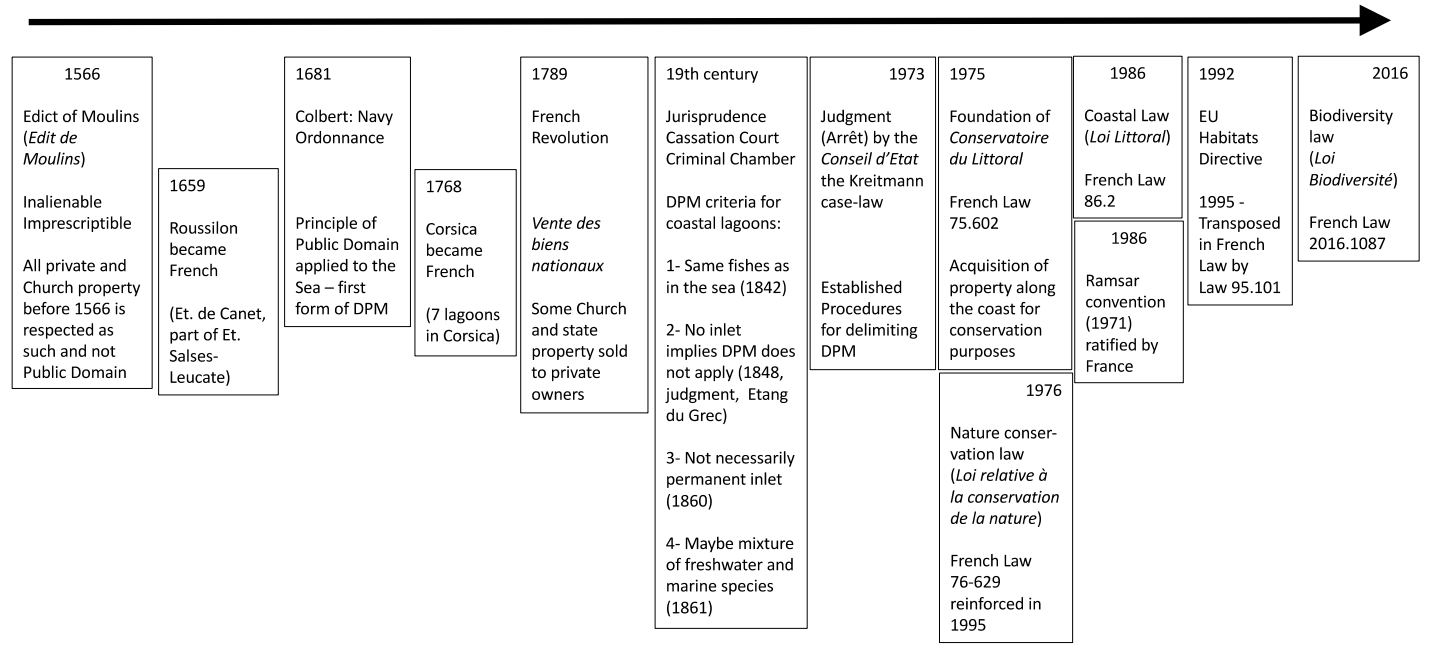

Figure 1: Timeline listing the most important legislation and historic events that have important implications for property regimes in coastal lagoons. 


\section{Results}

3.1 Analyses of the chronology of laws and jurisprudence in France related to property rights of coastal lagoons

Figure 1 lists the most important legislation and historic events that have important implications for property regimes in coastal lagoons. The Edict of Moulins was signed in 1566 by King Charles IX, with the aim to clarify a distinction in the Kingdom of France for the Royal property of the King (Domaine Royal) between the properties at his disposal for private issues (Domaine casuel) and the property that was eternally associated to the kingdom (Domaine fixe), i.e. the King should legate the Domaine fixe to his successor. For the latter property, the Edict introduced the characteristics of inalienability and imprescriptibly meaning, respectively, that its property rights cannot be changed in the future and neither transferred nor sold to somebody else, and that the inalienability is exempt from subscription. Today, the current State Domain Code and the French General Code of the property of public persons (Code général de la propriété des persones publiques, CGPPP) inherited this difference, as for public property it differentiates between "Domaine Public" and "Domaine Privé" (L.3111-1 of the CGPPP) in analogy to the former "Domaine fixe" and "Domaine casuel", respectively. Hence, the Domaine Privé de l'Etat (DPE) translates as "private property of the State", which in English is an oxymora as private property is opposed to public property. The different forms of public domain are subjected to inalienability and imprescriptibly, while the "private property of the State" (DPE) is not and can be sold to third parties.

More than a century later (1681), the Colbert ordinance of the Navy introduced the Natural Maritime Domain (Domaine Public Maritime, abbreviated DPM) stating that DPM "shall be considered as the edge and shore of the sea including all that the tide covers and uncovers during the new and full moons and how far the biggest wave of March can reach on the beach". Because the original ordinance only mentioned the shores of the sea it left the issue of the coastal lagoons unsettled. The issue of how to accommodate the DPM for coastal lagoons was settled in the following centuries. Today, the DPM comprises the artificial DPM (harbours, sea-defense structures, navigation channels, etc.) and the natural DPM (Domain Public Maritime naturel). Table 1 gives the legal text 
in French for the natural DPM and its translation in English. The second point, i.e. des étangs salés, clearly refers to coastal lagoons.

Table 1: Definition of the natural Maritime Public Domain according French General Code of the property of public persons (Code général de la propriété des persones publiques, CGPPP) in French (left column), and its translation by the authors in English (right column).

\begin{tabular}{|l|l|}
\hline Le DPM naturel est inaliénable et constitué : & $\begin{array}{l}\text { In France the natural Maritime Public Domain } \\
\text { is inalienable and encompasses: }\end{array}$ \\
$\begin{array}{l}\text { 1- du sol et du sous-sol de la mer, compris } \\
\text { entre la limite haute du rivage (c'est-à-dire } \\
\text { celle des plus hautes mers), et la limite, côté } \\
\text { large, de la mer territoriale ; }\end{array}$ & $\begin{array}{l}\text { 1- the seafloor and its subsurface strata } \\
\text { between the upper level of the shoreline (i.e. } \\
\text { those of the highest tides), and the limit of the } \\
\text { territorial sea); }\end{array}$ \\
$\begin{array}{ll}\text { 2- des étangs salés en communication } \\
\text { directe, naturelle et permanente avec la } \\
\text { mer; }\end{array}$ & $\begin{array}{l}\text { 2- the "salty ponds" (étangs salés) }= \\
\text { coastal lagoons with a direct, natural and } \\
\text { permanent communication with the sea; }\end{array}$ \\
$\begin{array}{ll}\text { 3- des lais et relais de la mer. } & \text { 3- sediment deposits of the sea along the } \\
\text { coastline. }\end{array}$ \\
\hline
\end{tabular}

The DPM definition of the étangs salés (Table 1) raises many problems for considering the entire range of environmental conditions for coastal lagoons and creates conflicts with the aforementioned scientific definition of coastal lagoons by Kjerve (1994). During, the $19^{\text {th }}$ century, many ambiguities were solved by the jurisprudence of the Criminal Chamber of the Cassation Court. Hence, in 1848 the judgement stipulated that coastal lagoons that do not have an inlet, but communicate with the sea only through a man-made canal do not belong to the natural DPM (Cuënot et al., 1851). Etang salé suggest that salinity should be similar to the adjacent sea (i.e. a salinity of about 35 in the adjacent Gulf of Lion) and raises the question of whether mesohaline (salinity between 5 and 18) and oligohaline coastal lagoons (salinity lower than 5) could be included in the natural DPM? However, salinity measurements were not yet commonly used in the $19^{\text {th }}$ century. While a first judgment in 1842 first specified that the lagoon 
should be home to the same fish species as in the adjacent sea, later this was rectified by a judgment in 1861 stipulating that the lagoon may also hold a mixture of freshwater and seawater species. This allowed to include many of the meso- and oligohaline coastal lagoons in the DPM. Finally, a judgment in 1860 stipulated that the inlet maybe temporarily closed. An example is the Etang de la Palme, where the inlet completely closes off every year (Larue and Roquet, 2016). Finally, while astronomic and meteorological tides have been taken into account since the Navy ordonnance of Colbert, more precise procedures for delimitation of the DPM were introduced in 1973 by a judgment (arrêt) of the Conseil d'Etat (the Kreitmann case-law).

While, these abovementioned Court trials focused on challenging the definition of the DPM itself, claims of private ownership of coastal lagoons have also been based on invoking pre-existing private property rights. Hence, jurisprudence followed by its inclusion in law, fixed the date of retroactivity of the DPM at 1566, the year of the Edict of Moulins. This means that public domains cannot be retroactively enforced prior to the Edict of Moulins (Torquebiau, 1965) implying that all private and Church properties existing before 1566 were to be respected and could thus not be included in the DPM. Therefore, the Royal and the Navy's administrations, under the Old Regime period and the Second Empire, respectively, carried out an inventory and put into place restitution procedures for rights prior to the Edict of Moulins (Feral, 2000). Numerous documents were produced by families from Languedoc and Camargue, attesting to ownership by their ancestors before 1566 of coastal lagoons (étangs salés) and other water bodies, as canals etc., as well as fisheries and maniguières. The latter are fishing rights linked to the land ownership of the coastal lagoons (Feral, 2020). The Minister of the Navy, in a decision of 30 July 1964, drew up a list recognising a large number of private owners of coastal lagoons and canals in the French Mediterranean (about 200 private owners of coastal lagoons, canals, fisheries, islets, rivers, streams etc.). In Roussillon (Pyrénées orientales Department), Et. De Canet and a small part of the Salses-Leucate Lagoon (Anse de la Roquette) were recognized as private property on the basis of Spanish titles after 1566 but before the Treaty of the Pyrenees of 1659 (Feral, 2020). Remarkably, in Corsica, annexed by France in 1768 and part of the Republic of Genova before, the seven coastal lagoons remained private property until quite recently. 
Private ownership was not always accepted by all sectors in society, as there have been many conflictual cases between the administration and private owners of coastal lagoons, first in front the civil courts (Torquebiau, 1965) and later in front of the administrative courts. The Navy administrations and coastal lagoon fishers organized in corporatist and professional organizations, the Prud'homies de Pêche (Féral, 1978; Féral, 1987), defended the idea of the coastal lagoon as a natural public domain for guaranteeing freedom of fishing. This resulted in an arm wrestling's with landlords (Hostiou, 1990; Féral, 2020a), who often claimed the exclusive private ownership of coastal lagoons with their rights to prohibit access and fishing by others. As shown before several procedures rehabilitated private property of coastal lagoons on the shores of the Mediterranean, even though their objective geographical location and hydrological features qualifies them to be part of the DPM. In this respect, a last notable case concerned the Et. de Vic opposing the fishers of Palavas and the Société des Salins de Villeneuve. The Trial (T.G.I. Montpellier, 26th June of 1964) decided to recognise private ownership and fishing rights based on an arbitration award by the Prévost de Maguelonne dating to 8 September 1190, which was taken up by a Judgment of the Parliament of Toulouse in 1617 and, therefore, prior to the Edict of Moulin of 1566 (Feral, in press). In addition, on the particular occasion of the French revolution in 1789, some Church and state property has been sold to private owners (vente des biens nationaux). Altogether, this explains why a large part of the coastal lagoon surface was private property before 1980 .

The Conservatoire de l'espace littoral et des rivages lacustres, known as the Conservatoire $d u$ littoral was created to prevent the destruction of natural habitats by the galloping urban and touristic developments. Enforced by Law (Law for the creation of the Conservatoire du Littoral, 1975) the Conservatoire du Littoral, hereafter referred to as the Conservatoire, is a public institution that has the prime mandate to safeguard natural areas along the coast. Therefore, it has acquired properties along the coast mainly by buying it from private owners. Occasionally, it hasq also used expropriation procedures and benefited from bequest. Upon acquisition, the property is formally private property of the Conservatoire, but normally within a year the property is shifted to the Public Domain as 'Domain Public du Conservatoire', which means that it has become imprescriptible and inalienable. Hence, its prime objective as a protected natural area 
cannot be changed and this is exempt from subscription. Later appeared the Nature Conservation Law in 1976, the Coastal Law (1986) and the EU Habitats directive in 1992, transposed in French law since 1995 by Loi $n^{\circ}$ 95-101, EU Habitats Directive, transposition into French Law (1995) and the Biodiversity Law (2016). Coastal lagoons are a priority habitat (i.e., $\mathrm{N}^{\circ} 1150$ *) in the EU Habitats directive (1992). On 1 December 1986, France also ratified the Convention on Wetlands of International Importance especially as Waterfowl Habitat (1971), known as the Ramsar Convention.

By law (Law for the creation of the Conservatoire du Littoral,1975), the management of the Public Domain of the Conservatoire is delegated to local partners. When seeking partnerships for this management, the Conservatoire invites local municipalities in the first place. Other decentralized public institutions, as Departments and Régions, as well as NGO's can also act as managers. These local partners establish a master plan for the management in collaboration with the Conservatoire, who has to give his final approval. In contrast, the natural DPM is nowadays managed by the Direction Départementale des Territoires et de la Mer (DDTM), which is a service of the French State that has a branch in all coastal Departments. Human uses, e.g., shellfish farming, salt extraction and touristic infrastructure are allowed on a temporal basis only through concession contracts. Fisheries has been traditionally regulated by a type of community-based ecosystem management through the Prud'homies de Pêche (Feral, 1978, Féral, 1987).

\subsection{Cartography of property regimes in French Mediterranean coastal lagoons}

Starting at the Spanish-French border in Occitanie, following the coastline clockwise and ending in Corsica, Figures 2, 3, 4, and 5 successively depict the cartography of property regimes and Table 2 provides quantitative data for the French Mediterranean coastal lagoons. The Etang de Canet, in the Roussillon region (Pyrénées orientales Department), which in principle qualifies well for the DPM, was private property, of which most has now been acquired by the Conservatoire. Thau lagoon, and almost all lagoons in the Aude Department are DPM (Fig. 2). However, as described before one smaller cadastral parcels, the Anse de la Roquette (44.9 ha) in the SW part of Etang Salses-Leucate, excluded from the DPM is private property. Moreover, in Etang Bages-Sigean there is another anomaly as one cadastral parcel in the SW is owned by the Aude Department. Some smaller lagoons in Figure 2, are either owned entirely by the Conservatoire 
(Bagnas) or shared among private property and the Conservatoire (Vendres, Pissevaches).

The lagoons close to Montpellier (Fig. 3) show a remarkable patchwork of property regimes. Only Etang D'Ingril Sud, Etang de l'Or and a small section of Etang de Méjean are DPM. Three of the four lagoons that have been separated from the coastline by the building of the Rhône-to-Sète canal (see 2.1 Study sites) are either largely (Et. d'Ingril Nord, Et. d'Arnel) or for a small part (Et. Méjean) private property of the State (DPE). The abandoned Salinas in Et. d'Ingril have been acquired by the Conservatoire. The municipality of Lattes owns about half of the Et. de Méjean, a small part of this lagoon along the NE shoreline is also private property. Etang de Vic and most of Etang Pierre Blanche are Public Domain of the Conservatoire, who acquired most of this by acquisition from private owners, while some cadastral parcels were transferred from the private State domain (DPE) to the Conservatoire. The municipality of Villeneuve-lèsMaguelone owns cadastral sectors in the Et. Pierre blanche and Et. de Prévost. The rest of the latter lagoon is private property (propriety of the diocese of Montpellier and managed by the 'Compagnons de Maguelone', an NGO in charge of maintaining the heritage of the Romanesque cathedral de Maguelone and engaged in social programmes). The Et. le Grec is entirely private property, which is based on the abovementioned 1848 judgment by the Cassation Court (Cuënot et al., 1851). The canal Rhône-to-Sète is Domaine Public Fluvial, which is managed by Voies Navigables de France (VNF).

None of the lagoons in the Camargue are DPM (Fig. 4A). In the Camargue of the Gard Department, the Etangs Charnier, Grey and Scamandre are owned by the local municipalities (Vauvert and Saint-Gilles). In the Bouche du Rhône Department, the Conservatoire has acquired more than $94 \%$ of the surface of Et. de Vaccares, while some smaller private properties still remain along the W., N., and E. shorelines. The four lagoons in the SE corner of the map in Fig. 4A all belong nowadays to the Conservatoire. Before 2009, these lagoons were privately owned by the Groupe Salins company and managed as salt preconcentration ponds for a major salt work in Salin de Giraud (De Wit et al. 2019). Since their acquisition by the Conservatoire, the management has changed and the lagoons are nowadays managed for nature conservation purposes. Close to 
Marseille (Fig. 4B), the Etang de Berre, the largest French Mediterranean lagoon (156 $\mathrm{km}^{2}$ ), is DPM with the particularity that its surface is not attributed to any municipality. The adjacent Et. de Bolmon has been acquired by the Conservatoire. Finally, in the Var Department, the Et. de Villepey (Fig. 5C) is also owned by the Conservatoire.

In Corsica, none of the seven coastal lagoons are DPM (Fig. 5). All these coastal lagoons were private properties until quite recently. The Department 'Haute Corse' acquired in 1994 the property of the largest lagoon in Corsica, i.e. Et. de Biguglia. Concerning the other six lagoons, two are still entirely privately owned (Et. de la Diana, Et. de la Ballistra), while others have been fully (Et. d'Urbino, Et. Santa Gulia, Et de Palu) or partially (Et. de Terrenzana) acquired by the Conservatoire and became Domaine Public du Conservatoire.

Table 2: Forty coastal lagoons in S. France and Corsica (Regions Occitanie, ProvinceAlpes-Côte d'Azure, Corse) listing their surfaces (ha.) from land cover data bases (equivalent to Corine Land Cover class 521, see Methods), mean depths and surfaces (in ha.) for the different classes of property regimes, and number of municipalities and Departments involved. Most water depths obtained from Le Fur et al., 2018). 


\begin{tabular}{|c|c|c|c|c|c|c|c|c|c|c|c|}
\hline \multirow{4}{*}{ Geographic name of lagoon } & \multirow{4}{*}{$\begin{array}{c}\text { Surface } \\
\text { (ha) }\end{array}$} & \multirow{4}{*}{ mean depth } & \multicolumn{4}{|c|}{ State property } & \multirow{4}{*}{$\begin{array}{c}\text { Department (CD) } \\
\text { surface (ha) }\end{array}$} & \multirow{4}{*}{$\begin{array}{l}\text { Municipality } \\
\text { surface (ha) }\end{array}$} & \multirow{4}{*}{$\begin{array}{l}\text { Private } \\
\text { surface (ha) }\end{array}$} & \multirow{4}{*}{$N^{\circ}$ municipalitites } & \multirow{4}{*}{$\mathrm{N}^{\circ}$ Departments } \\
\hline & & & \multicolumn{3}{|c|}{ Public domain regime } & \multirow{3}{*}{$\begin{array}{l}\text { Private regime } \\
\text { DPE } \\
\text { surface (ha) }\end{array}$} & & & & & \\
\hline & & & DPM & Sublic Domain of & Conservatoire & & & & & & \\
\hline & & & surface (ha) & surface (ha) & $\begin{array}{c}\text { acquired since } \\
\text { year }\end{array}$ & & & & & & \\
\hline Etang de Canet & 620.05 & 0.6 & & 539.93 & 1978 & & & & 80.1 & 1 & Pyrenées orientales \\
\hline Etang de Salses-Leucate & 5305.7 & 1.7 & 5350.6 & & & & & & 44.9 & 6 & $\begin{array}{l}\text { Pyrenées orientales / } \\
\text { Aude }\end{array}$ \\
\hline Etang de la palme & 577.6 & 0.6 & 577.6 & & & & & & & 1 & Aude \\
\hline Etang Bages-Sigean & 3828.0 & 1.3 & 3529.8 & & & & 298.2 & & & 5 & Aude \\
\hline Etang de l'Ayrolle & 1463.8 & 0.7 & 1463.8 & & & & & & & 1 & Aude \\
\hline Etang de Gruissan & 149.6 & 0.7 & 149.6 & & & & & & & 1 & Aude \\
\hline Etang du Grazel & 174.8 & less than $1 \mathrm{~m}$ & 135.7 & & & & & & & 1 & Aude \\
\hline Etang de Pissevache & 125.93 & less than $1 \mathrm{~m}$ & & 97.8 & 2014 & & & & 22.4 & 1 & Aude \\
\hline Etang de Vendres & 352.3 & 0.2 & & 65.1 & 1986 & & & & 265.6 & 1 & Hérault \\
\hline Etang de Bagnas & 168.13 & 0.6 & & 168.1 & 1991 & & & & & 1 & Hérault \\
\hline Etang de Thau & 6961.3 & 4.9 & 6961.3 & & & & & & & 9 & Hérault \\
\hline & & & & & & & & & & & \\
\hline Etang des Mouettes & 41.9 & 0.8 & & 41.9 & 2001 & & & & & 1 & Hérault \\
\hline Etang d'Ingril Sud & 257.53 & 0.7 & 262.03 & & & & & & & 1 & Hérault \\
\hline Etang d'I'Ingril Nord & 288.6 & 0.8 & & 54.0 & 1980 & 249.2 & & & & 1 & Hérault \\
\hline Etang de Vic & 1241.0 & 1.0 & & 1262.3 & 1982 & & & & & 1 & Hérault \\
\hline Etang de Pierre Blanche & 322.8 & 0.6 & & 282.4 & 1982 & & & 68.4 & 27.1 & 2 & Hérault \\
\hline Etang de l'Arnel & $548.0\}$ & 0.6 & & 129.9 & 1992 & 427.5 & & & & 2 & Hérault \\
\hline Etang du Prévost & 247.63 & 0.8 & & & & & & 33.5 & 256.4 & 2 & Hérault \\
\hline Etang du Méjean & 750.93 & 0.7 & 196.7 & & & 58.2 & & 490.0 & 22.8 & 2 & Hérault \\
\hline Etang du Grec & 139.6 & 0.5 & & & & & & & 193.3 & 1 & Hérault \\
\hline Etang de l'or & 3234.8 & 1.1 & 3069.6 & 341.1 & 1992 & & & & 35.1 & 6 & Hérault \\
\hline & & & & & & & & & & & \\
\hline Etang du Charnier & 495.5 & 0.9 & & & & & & 495.5 & & 1 & Gard \\
\hline Etang du Grey & 131.8 & 0.9 & & & & & & 131.8 & & 1 & Gard \\
\hline Etang de Scamandre & 585.2 & 1.2 & & & & & & 585.2 & & 2 & Gard \\
\hline Etang I'Impérial & 1641.0 & less than $1 \mathrm{~m}$ & & & & & 1641.0 & & & 1 & Bouches du Rhône \\
\hline Etang de Vaccares & 6476.7 & less than $1 \mathrm{~m}$ & & 5992.0 & 2006 & & & & 358.6 & 1 & Bouches du Rhône \\
\hline Etang de Galabert & 412.5 & less than $1 \mathrm{~m}$ & & 409.7 & 2007 & & & & & 1 & Bouches du Rhône \\
\hline Etang de Fangassier & 345.0 & less than $1 \mathrm{~m}$ & & 344.7 & 2007 & & & & & 1 & Bouches du Rhône \\
\hline Lagune et Etang de Beauduc & 1210.5 & less than $1 \mathrm{~m}$ & & 1207.4 & 2007 & & & & & 1 & Bouches du Rhône \\
\hline Etang de Vaisseau & 453.2 & less than $1 \mathrm{~m}$ & & 452.1 & 2007 & & & & & 1 & Bouches du Rhône \\
\hline Etang de Berre & 15640.6 & 4.9 & 15640.6 & & & & & & & not in municip & Bouches du Rhône \\
\hline Etang de Bolmon & 285.6 & 1.3 & & 285.6 & 1994 & & & & & $\mathrm{~m}_{2}$ & Bouches du Rhône \\
\hline Etang de Villepey & 81.7 & & & 81.7 & 1982 & & & & & 1 & $\mathrm{Var}$ \\
\hline & & & & & & & & & & & \\
\hline Etang de Biguglia & 1373.8 & 1.5 & & & & & 1341.2 & & & 3 & Haute Corse \\
\hline Etang de Terenzana & 36.5 & less than $1 \mathrm{~m}$ & & 14.4 & 1980 & & & & 22.3 & 2 & Haute Corse \\
\hline Etang de la Diana & 551.2 & $=\underbrace{}_{3.5}$ & & & & & & & 544.0 & 2 & Haute Corse \\
\hline Etang Urbino & 751.73 & 4.2 & & $751.7\}$ & 2007 & & & & & 1 & Haute Corse \\
\hline Etang de Palu & 111.6 & 0.8 & & 106.2 & 1981 & & & & & 2 & Haute Corse \\
\hline Etang de Santa Giulia & 275.3 & less than $1 \mathrm{~m}$ & & 275.3 & 1981 & & & & & 1 & Corse du Sud \\
\hline Etang de Balistra & 29.7 & less than $1 \mathrm{~m}$ & & & & & & & 28.9 & 1 & Corse du Sud \\
\hline & & & & & & & & & & & \\
\hline Total & 57688.9 & & 37337.2 & 12903.4 & & 734.9 & 3280.4 & 1804.3 & 1901.4 & & \\
\hline$\%$ of lagoon surface & 100.5 & & 64.7 & 22.4 & & 1.3 & 5.7 & 3.1 & 3.3 & & \\
\hline
\end{tabular}

1) Negotiations for the acquisition of cadastral parcels in Et. Balistra by the Conservatoire have started since 2015.

2) Note that the sum of cadastral parcels is slightly above $100 \%$ of total lagoon surface because the shorelines for the coastal lagoons often do not fit to the cadastral boundaries.

Table 2 resumes the information in a quantitative way. The total lagoon surface is about $577 \mathrm{~km}^{2}$. DPM occurs in twelve of the 40 lagoons, either the lagoon is partially DPM (e.g., Et. Salses-Leucate, Et. Bages-Sigean, Et. de Méjean) or entirely DPM (Et. de Thau, Et. de Berre). Despite the fact that this is a minority of lagoons, DPM represents almost $65 \%$ of the total lagoon surface as it includes all the larger lagoons. Private state property of the (DPE) only covers $1.3 \%$. Recently, 137.7 ha of private state property (DPE) in the Palavas lagoon complex (cf. Fig. 3) has been retroceded to the Conservatoire. Properties by Departments and municipalities represents 5.7 and $3.1 \%$, respectively. Currently in 2020, private properties by third persons still existed in 12 of the 40 lagoons, although its surface only represents a very small $3.3 \%$ of the total surface. Before 1975, about 25 $\%$ of the lagoon surface was privately owned, but most of that has now been acquired by the Conservatoire. It also recovered surface from the DPM (Et. les Mouettes) following 
road construction through Et. d'Ingril sud. Table 2 also list the year of the first acquisitions by the Conservatoire in the different lagoons. This public body currently has property in twenty of 40 lagoons (22\% of the total lagoon surface), which has been designated as Public Domain of the Conservatoire and safeguarded for nature conservation purposes, as such being also inalienable and imprescriptible. In addition, the privately owned Et. de Biguglia was acquired by the 'Haute Corse' Department in 1994. Another aspect shown by the Figures 2, 3, 4 and 5 and Table 2 is that the area of many of the larger lagoons belong to different municipalities, up to 9 different municipalities as for Et. de Thau. The Et. de Salses-Leucate has even parts in two different Departments (Pyrenées orientales, Aude).

\section{Discussion}

The property regimes of Mediterranean coastal lagoons are remarkably variable in South France (Figs. 2, 3, 4, and 5), despite the fact that French legislation (GCPPP) exists which accommodates the status of public property as Domaine Public Maritime (DPM) for these ecosystems. To the best of our knowledge this is a first extensive study of property regimes of coastal lagoons in a Mediterranean country. We performed a search in web of science with the search words "Law" and "Coast" and "Property" that yielded 123 documents. A screening of these documents showed that none of them corresponded to a comparable study on property regimes of coastal lagoons. In this respect, we could only compare our study with an FAO report (Cataudella et al., 2015) that succinctly states that many of the Venetian valli in Italy have private owners; while in Albania, Greece and Tunisia, all coastal lagoons are public domain and in Egypt, four lagoons belong to the public domain and one is owned by a public company. This shows that the public property of the sea and the coastal aquatic ecosystems not only traces back to Roman law (see Introduction), but rather also presents a tradition in Islamic law (Facchini and Falque, 2012; Khalilieh, 2019). We believe that it is very important to study the property regimes of coastal lagoons as these have important implications for their management, particularly in view of increasing needs for managing these ecosystems for the conservation of habitats and species (c.f., E.U. Habitats Directive, 1992). While, some scholars from neo-liberal schools of thought argue in favour of privatization of ecosystems for biodiversity conservation, it has been shown that in most cases in the coastal zone privatization has a very negative impact both for biodiversity 
conservation as well for local populations (Cabral and Aliño, 2011). However, dedicated NGO's may act as private owners with a prime objective for nature conservation. For example, the National Trust and Natuurmonumenten have acquired large natural areas along the coasts in the UK and Netherlands, respectively. In France, no large dedicated NGOs exist that acquire large areas for nature conservation purposes, while the smaller NGO ASPAS (Association pour la protection des animaux sauvages) actively acquiring properties for nature conservation purposes has no properties on the coast. Therefore, nature conservation on the French coasts has mainly relied on public policies. Hence, the Conservatoire du Littoral was created in 1975 to acquire cadastral parcels along the coast and safeguard them as public domain protected areas. Therefore, it is entitled to use land acquisition, bequest and expropriation procedures. Before 1980, private properties existed in 23 of the 40 coastal lagoons, representing about a quarter of the total lagoon surface. Since 1980, the Conservatoire also became active to acquire these private coastal lagoon properties.

How can the importance of previous private property of coastal lagoons be explained and why are property regimes still highly variable in some areas? In the introduction, we forwarded two hypotheses for explaining private property of coastal lagoons, which apparently is in conflict with the definition of the Maritime Public Domain (DPM) in the French law CGPPP. The first hypothesis, i.e. the private property existed in the past before the DPM was implemented and has been passed through inheritance, certainly applies for the Et. de Prévost and Et. de Pierre Blanche, where Church property of the diocese of Maguelone existed since the $12^{\text {th }}$ century. The diocese was transferred in 1536 to Montpellier, while keeping its properties in the lagoons and surroundings. The lagoons were exploited for fisheries and salt extraction. Hence, the respect of these properties was in agreement with the jurisprudence stating that retroactivity of DPM implementation is not applicable before 1556 (Edict of Moulins). Nevertheless, these properties were confiscated during the French revolution and sold ('vente des biens nationaux' see Fig. 1) to private persons. In 1949 these private properties were bequeathed to the diocese of Montpellier and thus returned to the Church (Barruol et al., 2017). Roussillon (with Et. de Canet and part of Et. Salses-Leucate) and Corsica (7 coastal lagoons) were integrated in the Kingdom of France after 1566 and Corsica even after implementation of the DPM. Until recently, full private ownership of coastal 
lagoons was complete in Corsica and prevailing in Roussillon. The private ownership existing in these territories before their annexation by France was originally respected. The Conservatoire has been particularly active in acquiring property in these two regions (Fig. 5).

The vagueness of the juridical text (Table 1), which does not cope with the full range of environmental conditions and thus conflicts with the scientific definition (Kjerve, 1994) of coastal lagoons, has given rise to many trials at the Cassation Court during the $19^{\text {th }}$ century (Fig. 1). The Navy ordonnance of Colbert defined the coastline and the sea as a public domain and included already some first descriptions on how to delimit this domain taking the astronomic and meteorological tides into account, although it did not mention the lagoons specifically. More precise procedures were introduced in 1973 by a judgment (arrêt) of the Conseil d'Etat (the Kreitmann case-law). The jurisprudence of 1848 stated that lagoons without a direct inlet and communicating with the sea through a man-made canal, do not qualify as DPM. This is in support for the second hypothesis, i.e., the legal text is not sufficiently precise to include all types of coastal lagoons and this has favoured the takeover of properties by private persons or institutions. Indeed, the immediate result of the 1848 judgement was that Et. du Grec became private property. In general, the jurisprudence implied that 6 of the 8 water bodies existing in the Palavas lagoon complex in the 19 ${ }^{\text {th }}$ century (Etangs du Méjean, de l'Arnel, de Vic, d'Ingril Nord, de Pierre Blanches et du Grec, see Methods) do not qualify for DPM. This explains the virtual absence of DPM in these lagoons (only a small section of Et. du Méjean is DPM) and the widespread occurrence of private state property (DPE), municipal properties and private properties (see Fig. 3). The Et. les Mouettes was created after 1950 as a result of road construction within Et. d'Ingril Sud, and currently is property of the Conservatoire. Natural processes, particularly accretion in deltas, may also contribute to separate the coastal lagoon from the sea. In South France, these deltas have been heavily modified by human intervention, meaning that the connection of these lagoons is now often through man-made channels. This may explain the previous widespread occurrence of private properties in the Rhône delta (Fig. 4) and in the Aude delta (Et. de Vendres, Fig. 2). In contrast to the aforementioned, other judgments by the Cassation Court during the $19^{\text {th }}$ century provided the necessary support for maintaining other coastal lagoons as DPM. Hence, coastal lagoons with temporary inlets (e.g. Et. de la 
Palme) and with lower salinities than seawater (mesohaline and oligohaline conditions) may qualify as DPM. On the other hand, it is surprising that the condition of naturalness of the inlet (Table 1) has only been challenged in Court a couple of times without success (e.g., C.A. Montpellier of 29 June 1849 and 6 February 1849), as nowadays most coastal lagoons in Occitanie have human-modified inlets.

Fragmented ownership of coastal lagoons is considered as highly problematic by coastal lagoon managers, particularly for those involved in nature conservation. Private ownership creates a work load for the managers, as they have to check that the different owners all respect the legislation and have to negotiate with them for other issues (e.g. Agri-environmental contracts, concertation for Natura 2000 objectives etc.). In this respect, it is very positive that the Conservatoire has acquired properties in 20 of 40 lagoons, which has resulted in reducing private lagoon property from around $25 \%$ to the still remaining $3.3 \%$. The private domain of the State can also be problematic as these areas depend directly on the fiscal services of the State often without clear targets for the management of these sites. It further creates uncertainties as the private domain of the state can be sold. The public domain of the State on the coast, either the Public Maritime Domain (DPM) and the Public Domain of the Conservatoire, confer large advantages for nature protection as these domains are imprescriptible and inalienable. These Public Domain status represent an institutional solution for the commons, and coastal nature should indeed be considered as valuable commons. Nevertheless, while the Public Domain of the Conservatoire has really been created for conservation of the littoral nature commons, the DPM was not designed for this specific purpose. In addition, the DPM is not necessarily immutable as it may gain or lose surface with the shifting shoreline and infilling of coastal water bodies. Hence, the surfaces that are no longer submerged during astronomic and meteorological high tides leave the DPM, thus becoming private State property (DPE) and can then be sold to others (Hostiou, 1990). In addition, despite the inalienability, general interest can be invoked by the French State to declassify DPM into DPE (e.g., road construction through Et. d'Ingril sud, see above). The co-occurrence of the DPM and the Public Domain of the Conservatory in a coastal lagoon territory also create some difficulties for a coherent management. While the DPM is managed by the DDTM, for the management of the Public Domain of the Conservatory, by law (Law of the Conservatoire, 1975), this institution has to establish a 
partnership with a local entity to whom it should delegate the management. Hence, because of these legal constraints, the DPM and the Public Domain of the Conservatoire will have different managers, which does not always facilitate a coherent approach.

Beside the fragmented property regimes of Mediterranean coastal lagoons, these ecosystems are also often located on the territories of different municipalities. Etang de Thau, which is entirely DPM (Fig. 2), is spread out over 9 municipalities. The Palavas lagoon complex with its highly fragmented property regimes (Fig. 3) covers 7 municipalities. This means that intercommunal (multi-municipal) collaboration has often been used to act as a coordinator for the management of these coastal lagoons. In practice this means that the intercommunal collaboration structures can act as the management partners of the Conservatoire and that they often hold the role of coordinator for the Natura 2000 lagoon sites. The GEMAPI law (2017), based on earlier decentralization laws, regulate the management of aquatic systems and prevention of inundations. The GEMAPI law (2017) has re-enforced the competencies of the intercommunal collaboration structures. Nevertheless, the GEMAPI law (2017) has also created institutional complications as the competences for environment have been transferred from the municipalities to larger administrative units as metropoles and agglomerations for those municipalities that are members of such units. In practice this means that for managing the coastal lagoons the metropoles and agglomerations have to collaborate with rural municipalities for the management of the lagoon ecosystems. In S. France, coastal lagoons included in the Natura 2000 network are not recognized as Marine Protected Areas (Chaboud and Galletti, 2007), but rather treated as Protected Areas on the continent. The Natural Regional Parks of the PNR Narbonnais en Méditerranée and PNR Camargue comprise many lagoons. Four major coastal lagoon areas in continental S. France (Et. Salses-Leucate, Narbonnais lagoon complex, Palavas lagoon complex and Camargue) and three lagoons in Corsica (Ets. Biguglia, Urbino and Palu) have been designated as wetlands of international importance according the Ramsar convention. Other Protected Area status also occur. Recent developments of the French environmental Code request to take ecological connectivity into account in marine and coastal spatial planning. The difficulty is now to integrate these ecological objectives into public domain law, which includes administrative legislation. 
The DPM and the Public Domain of the Conservatoire in a coastal lagoon do not exclude human access and natural resource exploitation. The terminology developed by Ostrom and colleagues (Schlager and Ostrom, 1992; Ostrom and Hess, 2007) for the actions allowed for the different types of actors is very useful in this respect. The Law for the creation of the Conservatoire du Littoral (1975) requests that citizens can visit the sites of the Public Domain of the Conservatoire. Hence, these areas may not be completely closed as fortresses for nature conservation (In French: "La Nature sous cloche" approach). The modalities of the visits should of course be regulated by the managers and agreed with the Conservatoire in the management master plan. Hence, the citizens typically have Access sensu Ostrom and Hess (2007), i.e., the right to enter a defined physical area and enjoy nonsubtractive benefits (for example, hike, canoe, sit in the sun). In the DPM, human uses, e.g., shellfish farming, salt extraction and touristic infrastructure are allowed on a temporal basis only through concessions. The concession holders thus hold temporary Withdrawal rights (Ostrom and Hess, 2007). Fisheries has been traditionally regulated by a type of community-based ecosystem management through the Prud'homies de Pêche (Feral, 1978, Féral 1987). For this resource the fishers affiliated to the Prud'homies de Pêche, can be considered as Proprietors sensu Schlager and Ostrom (1992) who have rights of access, extraction, management of the resource and exclusion, i.e. by excluding non-members from fishing in the lagoons. In conclusion, the Public domains on the coast should be managed as commons for the French citizens and for the human population in general with a major emphasis on the conservation of habitats and species. Any exploitation should be sustainable and not impair the natural heritage. This target is supported by the EU Habitats Directive (1992), which designated coastal lagoons as a priority habitat, thus recognizing that the EU member states that collectively have a specific responsibility for the conservation of this habitat.

Coastal lagoons thus represent a valuable commons for humanity because of their biodiversity, natural and cultural heritage, and natural resources. For their efficient protection, it appears most efficient that the surfaces of these water bodies are withdrawn from the over-heated economic markets on the coast worldwide to guarantee their long-term protection. Other methods for protection include legal regulation and contract-based solutions. As shown above, the latter may create 
complications for the managers when the property regimes are fragmented. Moreover, in the European Union, the Water Framework Directive recognizes water as a common resource. This creates a duality for the owner of a given water body, who owns the bottom and the sediment, but has to respect the water that exchanges along an aquatic continuum as a common good. Maritime public domain can thus present a good opportunity for environmental protection of coastal lagoons in many countries where this National State property regime is rooted in Roman and Islamic laws. However, in this paper we show that this principle was not fully applied in France and that this incongruence can be explained by a historical process. Furthermore, the example in France shows that its Maritime public domain (DPM) was historically not designed for nature protection, as this represent a demand that has emerged only since the 1970's for coastal lagoons. Hence, we call for a comparative study on legislation and property regimes of coastal lagoons and study how different countries have managed resource exploitation, conservation and adopted solutions to emerging problems and needs. As mentioned dedicated NGO's can perform a role to withdraw surfaces from economic markets for long-term nature protection, while the solution in France has been acquisition by a public body, the Conservatoire, with a specific mandate for nature protection. Nevertheless, on a European and global level there is very little quantitative data available concerning property regimes of coastal lagoons, implication of public law and the environmental Code, and the link with their management as protected areas. Furthermore, using the socio-ecosystems frameworks of Orstrom and Berkes it will be most interesting to study how the different rights for resource exploitation and access of these commons are regulated in national laws and customs.

\section{Conflict of Interest}

The authors declare no conflict of interest.

\section{Funding}

This study has been financially supported by the DRIIHM LabEx (ANR-11-LABX0010_DRIIHM), “Device for Interdisciplinary Research on human-environments 
Interactions" within the framework of the Human-environment observatory "Mediterranean coastline".

\section{Acknowledgements.}

We thank the coastal lagoon managers Laurianne Versluys (Perpignan Méditerranée Métropole), Laurence Fonbonne (Syndicat RIVAGE Salses-Leucate), Julie Bertrand (ADENA), Hélène Fabrega (SIEL), Yves Cherainertrand (SNPN), Gaël Hemery (PNR de la Camargue), Elisabeth Le Corr (GIPREB), and François Galeazzi ('Haute Corse' Department) for providing information and sharing their opinions. 


\section{References}

Anthony, A., J. Atwood, P. August, C. Byron, S. Cobb, C. Foster, C. Fry, A. Gold, K. Hagos, L. Heffner, D. Q. Kellogg, K. Lellis-Dibble,J. J. Opaluch, C. Oviatt, A. Pfeiffer-Herbert, N. Rohr, L. Smith, T. Smythe, J. Swift, Vinhateiro, N., 2009. Coastal lagoons and climate change: ecological and social ramifications in U.S. Atlantic and Gulf coast ecosystems. Ecol Soc 14(1): 8. http://www.ecologyandsociety.org/vol14/iss1/art8/

Barruol, G., Garnotel, A., Raynaud, C., 2017. Maguelone de l'antiquité à nos jours. Les Compagnons de Maguelone, Palavas-les-Flots. 144 pp.

Berkes, F., 2006. From community-based resource management to complex systems. Ecol Soc 11(1): 45.: http://www.ecologyandsociety.org/vol11/iss1/art45/

Biodiversity Law, 2016. Loi n 2016-1087 du 8 août 2016 pour la reconquête de la biodiversité, de la nature et des paysages (Loi Biodiversité) https://www.legifrance.gouv.fr/affichTexte.do?cidTexte=JORFTEXT000033016237\&cat egorieLien=id (accessed 23 July 2020)

Cabral, R.B., Aliño, P.M., 2011. Transition from common to private coasts: consequences of privatization of the coastal commons. Ocean Coast. Manage. 54, 66e74.

Cataudella S., Crosetti D., Massa F. (eds), 2015. Mediterranean coastal lagoons: sustainable management and interactions among aquaculture, capture fisheries and the environment Studies and Reviews. General Fisheries Commission for the Mediterranean. No 95. Rome, FAO. 278 pp.

Chaboud C., Galletti, F., 2007. Les aires marines protégées, une catégorie particulière de territoires pour le droit et l'économie ", in: Froger G. and Galletti (Eds), Mondes en développement, Regards croisés sur les aires protégées marines et terrestres, 35, (138), éd.de Boeck, Bruxelles, pp. 27- 42.

Coastal Law, 1986. Loi n 86-2 du 3 janvier 1986 relative à l'aménagement, la protection et la mise en valeur du littoral (Loi Littoral). Légifrance.

https://www.legifrance.gouv.fr/affichTexte.do?cidTexte=LEGITEXT000006068963\&dat $\underline{\text { eTexte}=20100127}$ (accessed 23 July 2020)

Conservatoire du littoral. http://www.conservatoire-du-littoral.fr/ (accessed 29 July 2020).

Cuënot, S., Gelle, Th., Fabre, A., 1851. Journal du Palais. Recueil le plus ancien et le plus complet de la jurisprudence francaise, Imprimerie Guiraudet et Jouaust, Paris https://play.google.com/store/books/details?id=svhbAAAAcAAI\&rdid=booksvhbAAAAcAAJ\&rdot=1 (accessed 20 July 2020)

De Wit, R., Leruste, A., Le Fur, I., Sy, M.M., Bec, B., Ouisse, V., Derolez, V., Rey-Valette, H., 2020. A Multidisciplinary Approach for Restoration Ecology of Shallow Coastal Lagoons, a Case Study in South France. Front Ecol Evol 8:108. doi: 10.3389/fevo.2020.00108

De Wit, R., Vincent, A., Foulc, L., Klesczewski, M., Scher, O., Loste, C., Thibault, M., Poulin, B., Ernoul, L., Boutron, O. 2019. Seventy-year chronology of Salinas in southern France: 
Coastal surfaces managed for salt production and conservation issues for abandoned sites. J Nat Conserv 49: 95-107 https://doi.org/10.1016/j.jnc.2019.03.003

Direction départementale des territoires et de la mer (DDTM). https://www.ecologiquesolidaire.gouv.fr/services-deconcentres-du-ministere\#e1 (accessed 29 July 2020).

EU Habitats Directive (1992). Directive 92/43/EEC of the European Parliament and of the Council on the conservation of natural habitats and of wild fauna and flora. http://ec.europa.eu/environment/nature/legislation/habitatsdirective/index en.htm (accessed 28 April 2020)

EU Habitats Directive, transposition into French Law. 1995. Loi n 95-101 du 2 février 1995 relative au renforcement de la protection de l'environnement. https://www.legifrance.gouv.fr/affichTexte.do?cidTexte=JORFTEXT000000551804\&cat egorieLien=id

Facchini, F., Falque. M., 2012. Droit de propriété et performance environnementale sur les deux rives de la Méditerranée : essai interpretation, in: Falque, M., Lamotte. H. Biodiversite / Biodiversity: Droit de propriété, économie et environnement / Property Rights, Economics and Environment, Bryulant, pp.257-275.

Fenn, Jr., P.T., 1925. Justinian and the Freedom of the Sea. Am J Int Law 19, 716-727

Feral, F., 1978. La prud'homie des pêcheurs de Palavas, étude de la mort d'une institution. Collection économie et droit de l'environnement PPS Lyon.

Feral, F., 1987. Un hiatus dans l'administration et la politique des pêches maritimes : les prud'homies de pêcheurs en Méditerranée. in: Norois, $n^{\circ} 133-135$, Espaces côtiers et sociétés littorales. Colloque international des 28, 29 et 30 novembre 1986 à Nantes. pp. 355-369; doi : https://doi.org/10.3406/noroi.1987.7433

Feral, F., 2020. Dualisme juridique en Nouvelle-Calédonie et droit ancestraux sur les espaces marins, Ghislain Otis ed., Droits autochtones.

Feral, F., (in press). A la découverte des droits maritimes précoloniaux : réflexion sur le domaine public maritime naturel, des étangs d'Occitanie aux lagons du Pacifique, in Mélanges Christian Lavialle, Presses universitaires de Toulouse.

French General Code of the property of public persons. Code général de la propriété des personnes publiques.

https://www.legifrance.gouv.fr/affichCode.do?cidTexte=LEGITEXT000006070299\&dat eTexte $=20080505$. (accessed 27 April 2020)

GEMAPI Law, 2017. Loi nº 2017-1838 du 30 décembre 2017 relative à l'exercice des compétences des collectivités territoriales dans le domaine de la gestion des milieux aquatiques et de la prévention des inondations.

https://www.legifrance.gouv.fr/eli/loi/2017/12/30/INTX1730876L/jo/texte (accessed 28 April 2020)

Hostiou, R., 1990. Le domaine public naturel : consistance et délimitation. Revue juridique de l'Environnement Année 19904 pp. 469-481

https://www.persee.fr/doc/rjenv_0397-0299_1990_num_15_4_2638 
Khalilieh, H.S., 2019. Islamic Law of the Sea, Cambridge University Press, 300 pp.

Kjerfve, B., 1994. Coastal Lagoons. in: Kjerfve, B., Ed., Coastal Lagoon Processes, Elsevier Oceanographic Series, Amsterdam, pp 1-8.

Larue, J.P., and Rouquet, J. (2006). La lagune de La Palme (Aude, France) face au comblement et à l'eutrophisation. Physio-Géo 10, 45-60.

https://journals.openedition.org/physio-geo/4761

Law for the creation of the Conservatoire du Littoral. 1975. Loi n $75-602$ du 10 juillet 1975 portant création du conservatoire de l'espace littoral et des rivages lacustres. https://www.legifrance.gouv.fr/affichTexte.do?cidTexte=JORFTEXT000000700418\&dat eTexte $=19910416$ (accessed 29 July 2020)

Le Fur, I., De Wit, R., Plus, M., Oheix, J., Simier, M., Ouisse, V., 2018. Submerged benthic macrophytes in Mediterranean lagoons: distribution patterns in relation to water chemistry and depth. Hydrobiologia 808, 175-200. DOI: 10.1007/s10750-017-3421-y

McGlashan,D.J., Duck, R.W., Reid, C.T., 2005. Defining the foreshore: coastal geomorphology and British laws. Estuarine, Coastal and Shelf Science 62, 183-192. https://doi.org/10.1016/j.ecss.2004.08.016

Ostrom, E., Hess, Ch., 2007. Private and Common Property Rights. Available at SSRN: https://ssrn.com/abstract=1304699 or http://dx.doi.org/10.2139/ssrn.1304699

Schlager, E., Ostrom, E., 1992. Property-Rights Regimes and Natural Resources: A Conceptual Analysis, Land Econ 68, 249-262

Thompson, C.B., 2004. International Law of the Sea/Seed: Public Domain versus Private Commodity. Nat Resourc J 44, 841.

Torquebiau, A., 1965. L'aménagement du littoral languedocien et la situation juridique des étangs côtiers. PhD thesis in Law, University of Montpellier

Yavuz Özalp, A., Akıncı, H., 2016. Development and management of private property rights on coastal areas. Ocean Coastal Manage 121, 107-115

http://doi.org/10.1016/i.ocecoaman.2015.12.015 


\section{Legends and Footnotes to Tables:}

Table 1 legend:

Table 1: Definition of the natural Maritime Public Domain according French General Code of the property of public persons (Code général de la propriété des persones publiques, CGPPP) in French (left column), and its translation by the authors in English (right column).

Table 2 legend:

Table 2: Forty coastal lagoons in S. France and Corsica (Regions Occitanie, ProvinceAlpes-Côte d'Azur, Corsica) listing their surfaces (ha.) from land cover data bases (equivalent to Corine Land Cover class 521, see Methods), mean depths and surfaces (in ha.) for the different classes of property regimes, and number of municipalities and Departments involved. Most water depths obtained from Le Fur et al., 2018).

Table 2 footnotes:

1) Negotiations for the acquisition of cadastral parcels in Et. Balistra by the Conservatoire have started since 2015.

2) Note that the sum of cadastral parcels is slightly above $100 \%$ of total lagoon surface because the shorelines for the coastal lagoons often do not fit to the cadastral boundaries. 


\section{Legends to Figures:}

Timeline

\begin{tabular}{|c|c|c|c|c|c|c|c|c|c|c|}
\hline \multirow{2}{*}{\begin{tabular}{l}
\multicolumn{1}{c}{1566} \\
Edict of Moulins \\
(Edit de \\
Moulins) \\
Inalienable \\
Imprescriptible \\
All private and \\
Church property \\
before 1566 is \\
respected as \\
such and not \\
Public Domain \\
\end{tabular}} & & \multirow{3}{*}{$\begin{array}{l}1681 \\
\text { Colbert: Navy } \\
\text { Ordonnance } \\
\\
\text { Principle of } \\
\text { Public Domain } \\
\text { applied to the } \\
\text { Sea - first } \\
\text { form of DPM }\end{array}$} & \multirow{3}{*}{\begin{tabular}{|l}
1768 \\
Corsica \\
became \\
French \\
(7 lagoons \\
in Corsica)
\end{tabular}} & \multirow{3}{*}{\begin{tabular}{|l}
1789 \\
French \\
Revolution \\
\\
Vente des \\
biens \\
nationaux \\
some church \\
and state \\
property sold \\
to private \\
owners
\end{tabular}} & \multirow{3}{*}{$\begin{array}{l}\text { 19th century } \\
\text { Jurisprudence } \\
\text { Cassation Court } \\
\text { Criminal Chamber } \\
\text { DPM criteria for } \\
\text { coastal lagoons: } \\
\text { 1- Same fishes as } \\
\text { in the sea (1842) } \\
\text { 2- No inlet } \\
\text { implies DPM does } \\
\text { not apply (1848, } \\
\text { judgemment, Etang } \\
\text { du Grec) } \\
\text { 3- Not necessarily } \\
\text { permanent inlet } \\
\text { (1860) } \\
\text { 4- Maybe mixture } \\
\text { of freshwater and } \\
\text { marine species } \\
\text { (1861) }\end{array}$} & \multirow{2}{*}{$\begin{array}{l}\quad 1973 \\
\text { Judgment } \\
\text { (Arrêt) by the } \\
\text { Conseil d'Etat } \\
\text { the Kreitann } \\
\text { case-law } \\
\\
\text { Established } \\
\text { Procedures } \\
\text { for delimiting } \\
\text { DPM }\end{array}$} & \multirow{2}{*}{$\begin{array}{l}1975 \\
\text { Foundation of } \\
\text { Conservatoire } \\
\text { du Littoral } \\
\text { French Law } \\
75.602 \\
\text { Acquisition of } \\
\text { property along } \\
\text { the coast for } \\
\text { conservation } \\
\text { purposes } \\
\end{array}$} & \begin{tabular}{|l}
\multicolumn{1}{c}{1986} \\
Coastal Law \\
(Loi littoral) \\
French Law \\
86.2 \\
\end{tabular} & \multirow{3}{*}{\begin{tabular}{|l|}
1992 \\
EU \\
Habitats \\
Directive \\
1995- \\
Transposed \\
in French \\
Law by \\
Law 95.101 \\
\end{tabular}} & \multirow[t]{3}{*}{ 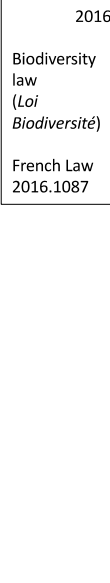 } \\
\hline & \begin{tabular}{|l|} 
Roussilon \\
became \\
French \\
(Et. de Canet, \\
part of Et. \\
Salses- \\
Leucate)
\end{tabular} & & & & & & & \begin{tabular}{|l|}
\multicolumn{1}{|c|}{1986} \\
Ramsar \\
convention \\
$(1971)$ \\
ratified by \\
France
\end{tabular} & & \\
\hline & & & & & & & \begin{tabular}{|l} 
Nature conser- \\
vation law \\
(Loi relative \\
la conservation \\
de la nature) \\
French Law \\
$76-629$ \\
reinforced in \\
1995
\end{tabular} & & & \\
\hline
\end{tabular}

Figure 1: Timeline listing the most important legislation and historic events that have important implications for property regimes in coastal lagoons. 


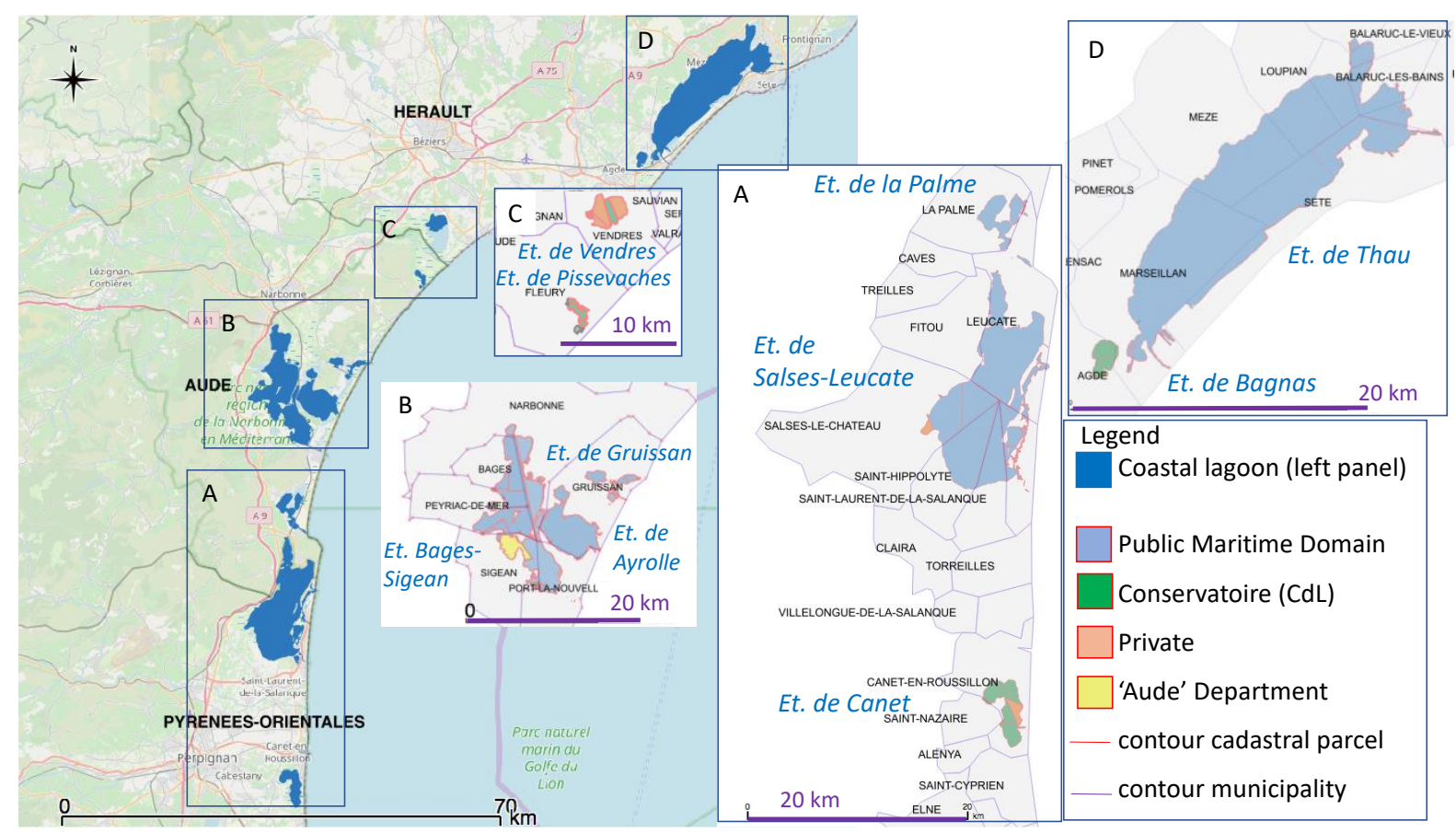

Figure 2: Geographic distribution, property regimes and municipalities of coastal lagoons in the Occitanie region (from the Spanish-French border to Frontignan).

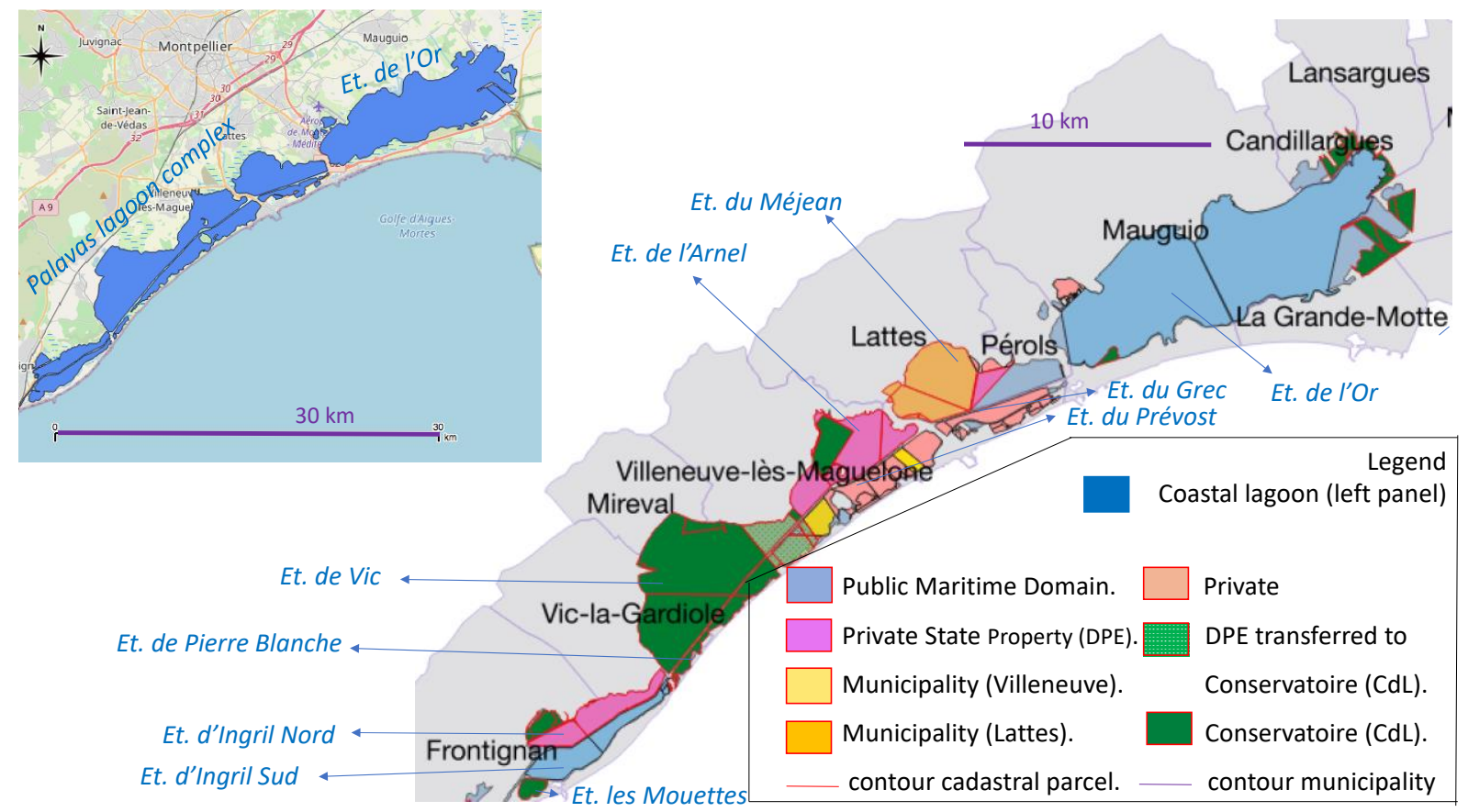

Figure 3: Geographic distribution, property regimes and municipalities of coastal lagoons in the Occitanie region close to Montpellier, the Palavas lagoon complex and Etang de l'Or. Upper left panel note Canal Rhône-to-Sète which is Fluvial Public Domain (Domaine Public Fluvial, DPF) 


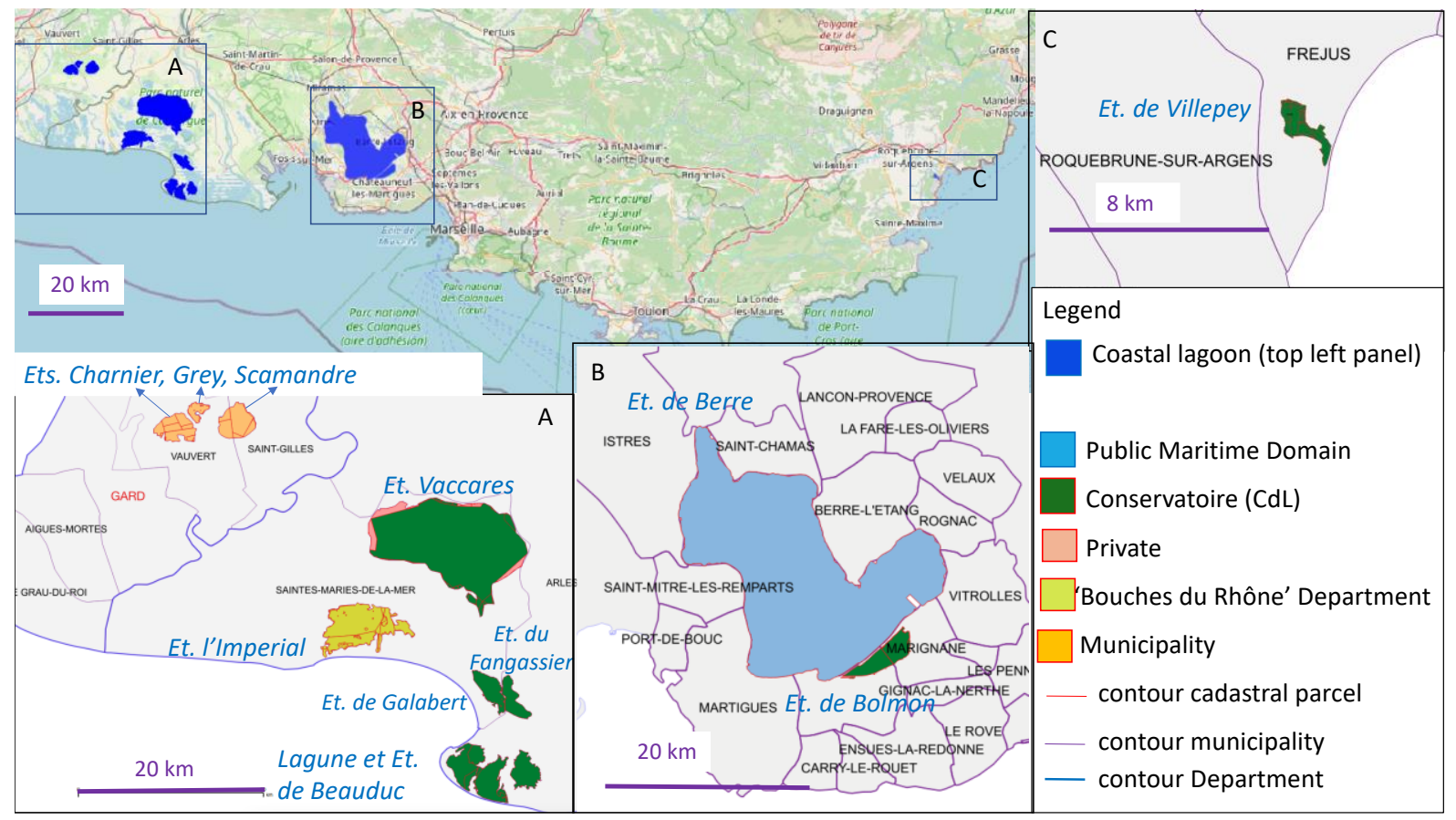

Figure 4: Geographic distribution, property regimes and municipalities of coastal lagoons in the Camargue and Province-Alpes-Côte d'azur region.

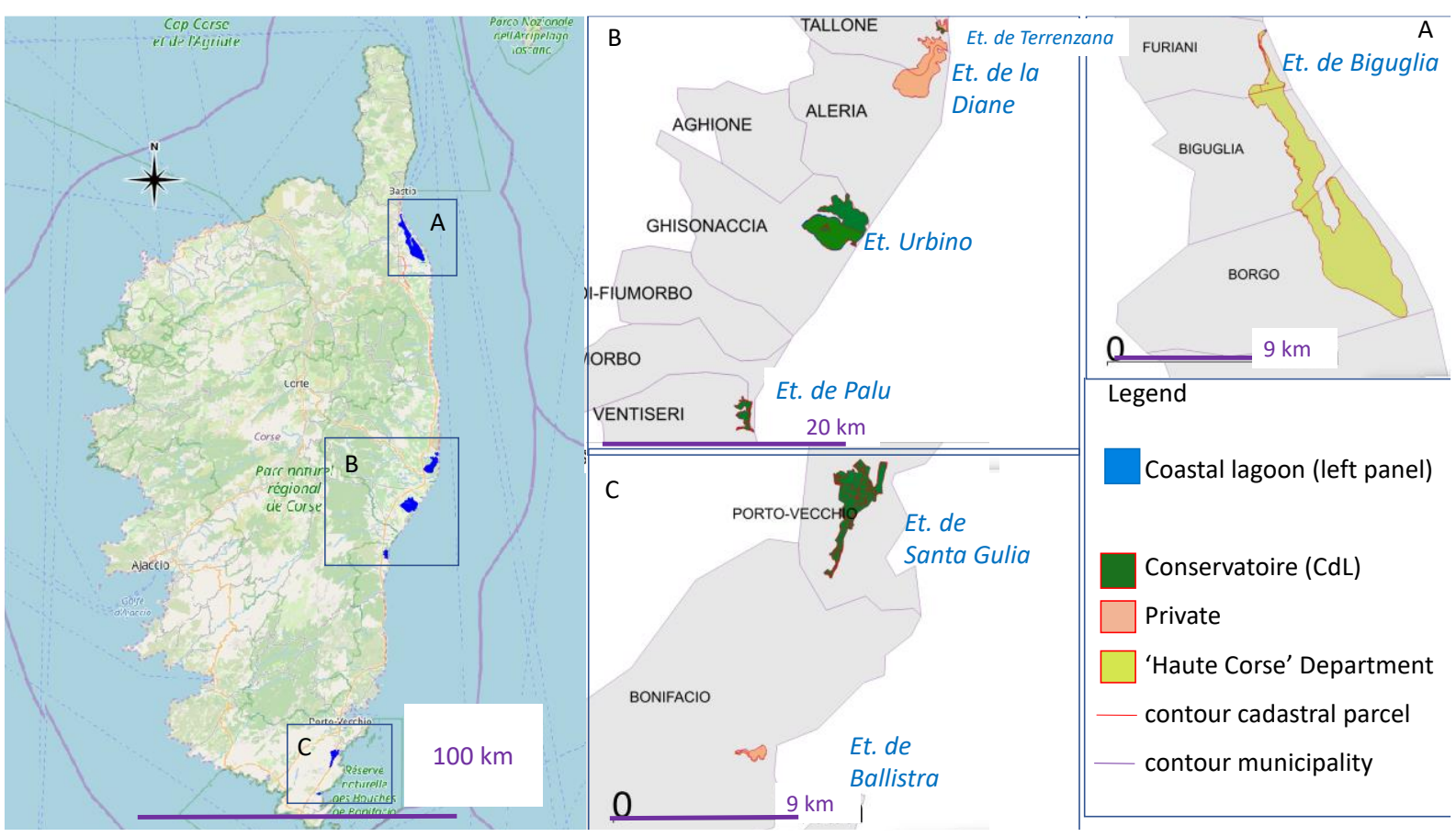

Figure 5: Geographic distribution, property regimes and municipalities of coastal lagoons in Corsica. 